\title{
Molecular Characterization of Chitinase (chil8-5) and its Expression in Trichoderma viride: Role on Nematode Egg Parasitism
}

\author{
R. Rajinikanth ${ }^{1}$, M.S. Rao ${ }^{1}$, K.V. Pavani ${ }^{2}$ and R. Umamaheswari ${ }^{1}$ \\ ${ }^{1}$ Division of Entomology and Nematology, ICAR-Indian Institute of Horticultural Research, \\ Hessaraghatta Lake post, Bengaluru, India - 560 089; \\ ${ }^{2}$ Gokaraju Rangaraju Institute of Engineering and Technology, Hyderabad, \\ India - 500090 \\ *Corresponding author
}

\section{A B S T R A C T}

\section{Keywords}

Biological control, chil8-5, Meloidogyne incognita, Enzyme assay, Trichoderma viride.

\section{Article Info}

Accepted:

08 November 2016

Available Online:

10 December 2016
Studies on molecular mechanism of Trichoderma viride in the pathogenesis action on nematode eggs mostly focus on the transcriptional activity of selected genes. However, studies investigating the exact role of a specific gene induction in $T$. viride on nematode egg parasitism are scant. The molecular interface between $T$. viride and Meloidogyne incognita eggs was investigated through the qPCR gene expression. The resultant gene chil8-5 of $T$. viride played a vital role in the induction of mycosis in the nematode eggs. Real-time PCR revealed that chil8-5 started up regulating at 2 hours post-inoculation (hpi) with maximum expression at $5 \mathrm{hpi}$, and the up regulation of the gene gradually decreased until $19 \mathrm{hpi}$. The chitinolytic enzyme chil8-5 plays a major role in egg parasitism in transcriptional activity in T.viride was characterized. Our present study proved that chil8-5 encodes one of the lytic enzymes required by $T$. viride to parasitise nematode eggs.

\section{Introduction}

Root-knot nematodes are major pests of agri-horticultural crops and cause severe yield loss to a wide range of vegetables in tropical and subtropical countries (Dababat et al., 2005; Khalil, 2012). Several fungal and bacterial pathogens gain easy entry into the plant root system affected by nematodes and lead to disease complexes (Taylor, 1990). Naturally occurring soil organisms that show antagonistic activity against plant parasitic nematodes are successfully used as biocontrol agents (Dong and Zhang, 2006). Of the many efficient biocontrol agents identified, only a few of them are successfully commercialized (Larkin et al., 1998; Meyer and Roberts, 2002). Among the several bacterial and fungal biocontrol agents used, Trichoderma viride is extensively used to control a wide range of plant parasitic nematodes (Al-Hazmi and Tariq, 2016; Kerry, 2000; Meyer et al., 2001; Shamalie et al., 2012). T. viride is an effective biocontrol agent against Meloidogyne spp. (Saeedizadeh, 2016). It significantly reduced the number of egg masses of $M$. incognita (Dababat et al., 
2007) and was effective against several fungal pathogens (Kapoor et al., 2010). Many successful reviews on the use of $T$. viride to control plant-parasitic nematode infestations on various crops have been reported (Rajinikanth et al., 2013; Rao et al., 2007; Sahebani and Hadavi, 2008; Sharon et al., 2001; Spiegel et al., 2007; Yang et al., 2010). Mycoparasitism exhibited by Trichoderma spp. has been well documented by many researchers (Howell, 2003; Savazzini et al., 2009; Szabo et al., 2012; Verma et al., 2007; Vinale et al., 2008) and applied for the biocontrol of phytopathogens.

Trichoderma spp. are highly competitive in root, soil, and foliar environments. It produces several lytic enzymes such as chitinases, proteases, lipase, and glucanases to degrade the cell wall components of pathogenic fungi (Blaszczyk et al., 2014; Chet et al., 1997; GajeraandVakharia, 2012; Geraldine et al., 2013; Parmar et al., 2015). Among all the enzymes, chitinase plays the most vital role in nematode egg parasitism by Trichoderma spp. by which the fungus ruptures the egg shell of the nematodes (Gortariand Hours, 2008). Mycoparasitism involves morphological changes, such as formation of appressorium-like structures and coiling, to penetrate a host (McIntyre et al., 2004).

Increase in chitinase activity through direct egg parasitism by Trichoderma spp. can reduce nematode infestation (Sharon et al., 2001; Suarez et al., 2004). Chitinase genes, such as chil8-5(chit42), chil8-12 (chit33), chi18-15 (chit36) (Viterbo et al., 2001, 2002), and nag, (Brunner et al., 2003) and their effective regulation against mycoparasitism have been extensively studied. Relative gene expression data was analysed using real-time qPCR and the 2$\triangle \Delta \mathrm{CT}$ method (Livak and Schmittgen, 2001).
In this study, experiments were conducted to evaluate chitinase chil8-5(chit42) gene expression, and variation in activity was determined at different time intervals using real-time PCR. The chitinase enzyme assay was performed to measure the activity in control and test samples under various conditions.

\section{Materials and Methods}

\section{Collection of the bioagent culture and nematode egg masses}

T. viride strain (ITCC No. 6889) was isolated and maintained at ICAR-Indian Institute of Horticultural Research on potato dextrose agar (PDA) using the cryopreservation method (Sudheer, 2010). A subculture of test inoculants of $T$. viride was prepared by placing a 5-mm culture disc on plates with solidified PDA and incubated for 3 days at $27 \pm 2^{\circ} \mathrm{C}$.Pure culture of the pathogenic root-knot nematode $M$. incognita was collected from nematodeinfected cauliflower plants at Doddaballapur (Bengaluru Rural, Karnataka, India), and presence of $M$. incognita was confirmed by the perineal cuticular pattern observed under a stereomicroscope (Hussey and Barker, 1973). The identified M. incognita was used for further studies.

\section{Assay of egg parasitism}

T. viride was pre cultured in PDA medium for 3 days. Approximately 5-8 egg masses of each carrying approximately 150-250 eggs of $M$. incognita were used for the assay. $T$. viride culture was used to observe endochitinase gene expression upon interaction with $M$. incognita. The egg masses were placed near the periphery of $T$. viride $\left(10^{8}\right.$ spores $\left./ \mathrm{mL}\right)$ mycelia in a $5-\mathrm{mm}$ wide zone in each PDA plate in vitro. To maintain sterile conditions, the PDA plates 
were sealed and incubated at $25^{\circ} \mathrm{C}$ in the dark and replicated thrice. Observations were recorded at various time intervals $[0,1$, $2,3,5,7,9,11,13,15,17$, and 19 h postinoculation (hpi)] to monitor the variation in chitinase gene expression. At each interval, $M$. incognita egg mass-colonised $T$. viride mycelia were collected and pooled from 10 plates. They were then flash-frozen in liquid nitrogen and stored at $-80^{\circ} \mathrm{C}$ for further downstream applications.

RNA extraction, cDNA synthesis, and
real-timePCR

RNA extraction was performed from $25 \mathrm{mg}$ of stored fresh fungal mats using a NucleoSpin Tissue extraction kit (Macherey-Nagal, Germany), following the supplier's instructions. After DNase treatment, RNA concentrations quantified at 260/280 nm were estimated using a NanoDrop spectrophotometer (Thermo Scientific-Nano drop light, USA). RNA was reverse-transcribed into a single-stranded cDNA using a Verso cDNA synthesis kit (Thermo Scientific, USA) following the supplier's instructions. Primers were designed using a web-based online primer design service (RozenandSkaletsky, 1999), Primer3 (http://fokker.wi.mit.edu/primer3). The endochitinase gene (chil8-5) was used for analyzing chitinase gene expression, and alfa-tubulin (Szabo et al., 2012) was used as a reference gene. PCR was performed using a Step One real-time PCR system (ABI7500, TR-PCR-Applied Biosystems) with SYBR green master mix (Takara Bio Inc, Japan) to examine DNA synthesis. Final reaction was performed in $25 \mu \mathrm{L}$ volumes, according to the manufacturer's instructions, containing 1:10 volume of cDNA and $1 \mu \mathrm{L}$ $(0.5 \mu \mathrm{M})$ of gene-specific forward and reverse primers (Table 1). All reactions were triplicated including a control with no template. Single gene amplification was confirmed by the presence of melting curves. The variation levels of chil8-5 expression were estimated using $\log 2 \mathrm{RQ}$ values with a 0 hpi steady state chitinase transcript at all remaining time points $(0,1,2,3,5,7,9,11,13,15,17$, and 19).

Each experimental setup of qPCR was designed and performed according to the Minimum Information for Publication of qPCR Experiments guidelines (Bustin et al., 2009). Alfa-tubulin was used as a normalisation control.

\section{Chitinase enzyme assay}

One gram of $T$. viride mycelium was homogenised in $2 \mathrm{~mL}$ of $0.1 \mathrm{M}$ sodium acetate buffer ( $\mathrm{pH} 5.0)$. The homogenate was centrifuged at $10,000 \mathrm{rpm}$ for $15 \mathrm{~min}$ at $4{ }^{\circ} \mathrm{C}$, and the supernatant was used for the chitinase enzyme assay. The protein concentration was estimated by the method of Lowry et al. (1951). T. viride chitinase activity was assayed with $200 \mu \mathrm{L}$ of colloidal chitin $(5 \mathrm{mg} / \mathrm{mL})$ and $200 \mu \mathrm{L}$ of enzyme solution. The mixture was incubated for $60 \mathrm{~min}$ at $40^{\circ} \mathrm{C}$, and the reaction was terminated by adding $1 \mathrm{~mL}$ of $1 \% \mathrm{NaCl}$ and centrifuged at $6000 \mathrm{~g}$ for $5 \mathrm{~min}$. The supernatant was boiled with $100 \mu \mathrm{L}$ of potassium tetraborate buffer for $3 \mathrm{~min}$. To this reaction, $3 \mathrm{~mL}$ of DMAB reagent $[10 \mathrm{~g}$ of dimethyl amino benzaldehyde in $100 \mathrm{~mL}$ of glacial acetic acid (12.5\%) and $10 \mathrm{M}$ chloridric acid (87.5\%)] was added. The mixture was incubated at $40^{\circ} \mathrm{C}$ for $20 \mathrm{~min}$, and the amount of $\mathrm{N}$-acetylglucosamine (GLcNAc) produced in the supernatant was determined by a previously described method (Zeilinger et al.,1999) and using GLcNAc as a standard. One unit of enzyme activity was defined as the amount of enzyme that catalysed the release of 1 $\mu \mathrm{molGLcNAc}$ in $60 \mathrm{~min}$ at $40^{\circ} \mathrm{C}$. 


\section{Results and Discussion}

Effect of chitinase (chi18-5) on eggs of $M$. incognita

Chitinase (chil8-5) gene expression pattern was studied at various time intervals as shown in Fig1. At $1 \mathrm{hpi}$, the expression gradually increased $(\log 2 \mathrm{RQ}$ fold change to 5.079 ) and at $2 \mathrm{hpi}$ to 5.201. The expression was observed at 3 and $5 \mathrm{hpi}(\log 2 \mathrm{RQ}$ fold change to 5.690 and 6.261) with a decrease in the expression observed at $7 \mathrm{hpi}$ to 5.923 . It was followed by gradual decrease in expression from 9 hpi $(\log 2 \mathrm{RQ}$ fold change to 5.217$)$ and at 11,13 , and 15 hpi $(\log 2 \mathrm{RQ}$ fold change to $3.874,3.516$, and 3.162). It was continued at $17 \mathrm{hpi}(\log 2 \mathrm{RQ}$ fold change to 2.314)and then final decrease to
1.392 at 19 hpi (Fig.1). Chitinase (chil8-5) is mainly involved in early stages of mycoparasitic process, which establishes a hyphal attachment with the host (Zeilinger $e t$ al., 1999). Results indicated that chitinase gene (chil8-5) played an important role in the M. incognita egg parasitism.

\section{Chitinase assay}

At room temperature, chitinase specific activity was $0.018 \mu \mathrm{mol} / \mathrm{min} / \mathrm{mL}$, whereas the chitinase activity increased to 0.038 $\mu \mathrm{mol} / \mathrm{min} / \mathrm{mL}$ invitro at $5 \mathrm{hpi}$ in the presence of $M$. incognita. The enzyme activity was measured at 5 hpi since the maximum chitinase (chil8-5) expression was observed.

Table.1 Primers for Endochitinase (Chi18-5) and Alfa-tubulin genes

\begin{tabular}{|l|l|l|l|l|}
\hline S.No & Gene & Forward Primer & Reverse Primer & $\begin{array}{l}\text { NCBI AC } \\
\text { Numbers }\end{array}$ \\
\hline 1 & Chil8-5 & CGGTATCTGGGATTACAAGG & GCCTCCCAGAACATGCTACC & KP271024 \\
\hline 2 & $\begin{array}{l}\text { Alfa- } \\
\text { tubulin }\end{array}$ & CTGGTCTTCCCTCTCCCTCA & GGCAGCAACCTCCTCGTAAT & KP271025 \\
\hline
\end{tabular}

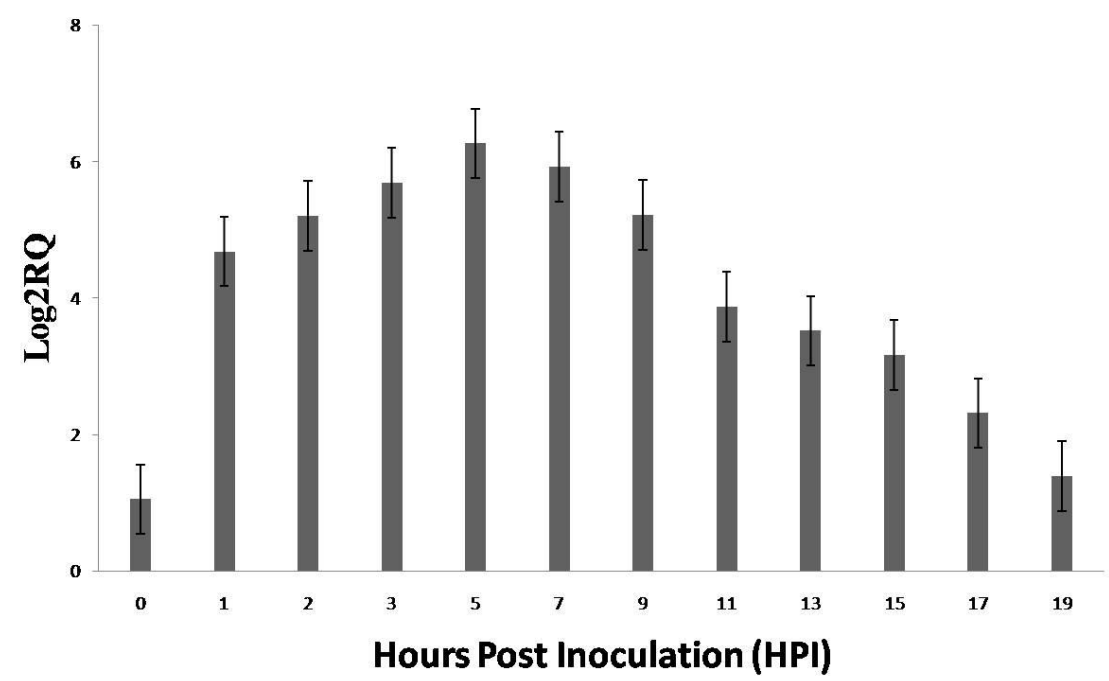

Fig 1. Chitinase (chi18-5) gene expression pattern at various Hours Post Inoculation (HPI) 
T. viride has a parasitic and symbiotic association with plants and other microbes (Kubicek and Harman, 1998; Perveen and Bokhari, 2012). This fungus was also found to be more resistant to natural and humanmade chemicals and toxins (Harman et al., 2004). Nematophagous fungi use specialised mycelial structures to entrap and thus kill and assimilate motile nematodes, eggs, and cysts (Nordbring-Hertz et al., 2006; Szabo et al., 2012). Trichoderma spp. utilize chitinase along with other enzymes (proteases, lipase, and glucanases) to degrade the cell wall of the pathogens (Boller and Mauch, 1988; Duo-chuan, 2006; Gortariand Hours, 2008; Seidl et al., 2005; Szabo et al., 2012).

Hence, T. viride is a major source of chitinolytic enzymes, and combinations of these fungal hydrolytic enzymes function effectively in chitin hydrolysation. The synergistic effect of chitin hydrolysis is one of the major factors contributing to the biocontrol ability of $T$. viride against a broad spectrum of chitin-containing plant pathogens (Brunner et al., 2003; Carsolio et al., 1994; Chet et al., 1998; Haran et al., 1995; Inbarand Chet, 1995; Kulling et al., 2000a; Viterbo et al., 2001).

In mycoparasitism, Trichoderma directly attacks the plant pathogen by excreting lytic enzymes such as chitinases, $\beta-1, \quad 3-$ glucanases, and proteases (Haran et al., 1996). Therefore, chitinase gene expression on nematode egg parasitism was clearly established at various time intervals. Trichoderma has the potential to produce cellwall-degrading enzymes in the presence of chitin in the growth medium. Trichoderma $\quad \beta$-1,3-glucanases are responsible for hydrolysis of phytopathogenic fungi during a mycoparasite attack (Matroudi et al., 2009). Colonisation by Trichoderma strains results in increased levels of defence-related plant enzymes, including various peroxidases, chitinases, $\beta$-1,3-glucanases (Harman et al., 2004).

Chitinase gene (Chil8-5) expression studies revealed that $T$. viride possesses excellent biocontrol abilities against $M$. incognita. It is involved in direct nematode egg parasitism. Chitinase activity varied depending on the influence by the expression of chitinase. Using the fundamental knowledge of the present study, we aim at developing new strains with chil8-5 over expression that may help in controlling nematodes effectively and confirm the role of chitinase in $T$. viride on egg parasitism. Additional studies on the mode of action of other enzymes antagonistic to nematodes are needed.

\section{Acknowledgements}

The authors are thankful to the Director, ICAR-Indian Institute of Horticultural Research (IIHR), Bengaluru, India, for providing necessary facilities to conduct the experiments. The financial support from National Bank for Agriculture and Rural Development (NABARD), Bengaluru, India, is greatly acknowledged. We are thankful to Arthikirubha A, Kamalnath M, Grace G N and Prabhu P, for their help to conduct RTPCR.

\section{References}

Al-Hazmi, A.S., and M. Tariq Javeed. 2016. Effects of different inoculum densities of Trichoderma harzianum and Trichoderma viride against Meloidogyne javanica on tomato. Saudi. J. B. Sci., 23 (2): 288292

Blaszczyk, L., M. Siwulski, K. Sobieralski, J. Lisiecka, and M. Jedryczka, 2014. 
Trichoderma spp.-application and prospects for use in organic farming and industry. J. Plant Protection Res., 54(4): 309-317

Boller, T., and F. Mauch, 1988. Colorimetric assay for chitinase. Meth. Enzymol., 161: 430-435

Brunner, K., C. K. Peterbauer, R. L. Mach, M. Lorito, S. Zeilinger, and C. P. Kubicek, 2003. The Nag1 Nacetylglucosaminidase of Trichoderma atroviride is essential for chitinase induction by chitin and of major relevance to biocontrol. Curr. Genet., 43(4): 289-295

Bustin, S.A., V. Benes, J.A. Garson, J. Hellemans, J. Huggett, M. Kubista, R. Mueller, T. Nolan, M. W. Pfaffl, G. L. Shipley, and J. Vandesompele, 2009. The MIQE guidelines: minimum information for publication of quantitative real-time PCR experiments. Clin. Chem., 55(4): 611622

Carsolio, C., A. Gutierrez, B. Jimenez, M. Van Montagu, and A. Herrera-Estrella, 1994. Characterization of ech-42, a Trichoderma harzianum endo chitinase gene expressed during mycoparasitism. Proceedings of the National Academy of Sciences of the United States of America.,91(23): 10903-10907

Chet, I., J. Inbar, and I. Hadar, 1997. Fungal antagonists and mycoparasites. In:Wicklow, D.T., Soderstrom, B. (Eds.), The Mycota IV: Environmental and Microbial Relationships. SpringerVerlag, p.165-184 (Berlin)

Chet, I., N. Benhamou, and S. Haran, 1998. Mycoparasitism and lytic enzymes. In: Harman, G.E., Kubicek, C.P. (Eds.), Trichoderma and Gliocladium, vol. 2, Taylor and Francis Ltd., London, p.153-172 (United Kingdom)

Dababat, A.A., R. A. Sikora, and R.,
Hauschild, 2005. Use of Trichoderma harzianum and Trichoderma viride for the biological control of Meloidogyne incognita on tomato. Commun.Agr. Appl. Biol. Sci., 71:(3 Pt B), 953-961

Dababat, Abd, Al-Fattah, A., and R. A. Sikora, 2007. Uese of Trichoderma harzianumand Trichoderma viride for the Biological Control of Meloidogyne incognita on Tomato. J. J.Agr. Sci., 3(3): 297-309

Dong, L.Q., and K. Q. Zhang, 2006. Microbial control of plant-parasitic nematodes: a five-party interaction. Plant Soil., 288(1-2): 3145.

Duo-Chuan, L. 2006. Review of fungal chitinases. Mycopathologia, 161(6): 345-360.

Gajera, H.P., and D. N.Vakharia. 2012. Production of lytic enzymes by Trichoderma isolates during in vitro antagonism with Aspergillus niger, the causal agent of collar rot of peanut. Braz. J. Microbiol., 43(1): 4352.

Geraldine, A.M., F. A. C. Lopes, D. D. C. Carvalho, E. T. Barbosa, A. R. Rodrigues,R. S. Brandao,C. J. Ulhoa, andM. L. Junior, 2013. Cell walldegrading enzymes and parasitism of sclerotia are key factors on field biocontrol of white mold by Trichoderma spp. Biol. Control., 67(3): 308-316.

Gortari, M.C., and R. A. Hours, 2008. Fungal chitinases and their biological role in the antagonism onto nematode eggs: A review. Mycol.Progr., 7(4):221-238.

Haran, S., H. Schickler, A. Oppenheim, and I. Chet, 1995. New components of the chitinolytic system of Trichoderma harzianum. Mycol. Res., 99(4):441446.

Haran, S., H. Schickler, and I. Chet, 1996. 
Molecular mechanisms of lytic enzymes involved in the biocontrol activity of Trichoderma harzianum. Microbiol., 142(9):2321-2331.

Harman, G.E., M.Lorito, J. M. Lynch, 2004. Uses of Trichoderma spp. to alleviate or remediate soil and water pollution. Adv. Appl. Microbiol., 56: 313-330.

Howell, C.R. 2003. Mechanisms employed by Trichoderma species in the biological control of plant diseases: the history and evolution of current concepts. Plant Dis., 87(1): 4-10

Hussey, R.S., and K. R. Barker, 1973. Comparison of methods of collecting inocula of Meloidogyne spp., including a new technique. Plant Dis. Rep., 57:1025-1028.

Inbar, J., and I. Chet, 1995. The role of recognition in the induction of specific chitinases during mycoparasitism by Trichoderma harzianum. Microbiol., 141(11):2823-2829

Kapoor, S., A. Jaiswal, and D.N. Shukla, 2010. Antagonistic effect of Trichoderma strains against Fusarium oxysporumf. Sp. Udum Buttler causing wilt of pigeon pea.Agr. Sci. Digest., 30(3):189-191

Kerry. B.R., 2000.Rhizoshere Interactions and the Exploitation of Microbial Agents for the Biological control of Plant Parasitic Nematodes. Annu. Rev. Phytopathol., 38(1):423-441

Khalil. E.D.H., A. Allam, and A. Tag Barakat, 2012.Nematicidal activity of some biopesticide agents and microorganisms against root-knot nematode on tomato plants under greenhouse conditions. J. Plant Prot. Res., 52(1):47-52

Kubicek, C.P., andG. E. Harman, 1998.Trichoderma and Gliocladium. Vol. 1. Basic Biology, Taxonomy and Genetics. Taylor and Francis, p. 264-
266 (London)

Kulling, C.M., R. L. Mach, M. Lorito, and C. P.Kubicek, 2000a. Enzyme diffusion from Trichoderma atroviride (=T. harzianum P1) to Rhizoctonia solani is a prerequisite for triggering of Trichoderma ech42 gene expression before mycoparasitic contact. Appl. Environ. Microbiol., 66(5):2232-2234

Larkin, R.P., and D. R. Fravel, 1998. Efficacy of various fungal and bacterial biocontrol organisms for control of Fusarium wilt of tomato. Plant dis., 82: 1022-1028

Livak, K.J., and T. D.Schmittgen, 2001. Analysis of relative gene expression data using real-time quantitative PCR and the 2- $\Delta \Delta \mathrm{CT}$ method. Methods., 25(4):402-408

Lowry, O.H.N.J., ALFarr. Rosebrough, and R. J. Randall, 1951. Protein Measurement with the Folin Phenol Reagent. J. Biol. Chem., 193:265-275

Matroudi, S., and M. R.Zamani, 2009. Antagonistic effects of three species of Trichoderma sp. on Sclerotiniasclerotiorum, the causal agent of canola stem rot. Egypt J. Biol., 11(1)

McIntyre, M., J. Nielsen, J.Arnau, V. H. Brink, and K. Hansen,2004. Proceedings of the 7th European Conference on Fungal Genetics. Copenhagen, (Denmark).

Meyer, S.L., andD. P. Roberts, 2002. Combinations of biocontrol agents for management of plant-parasitic nematodes and soil borne plantpathogenic fungi. J. Nematol., 34(1):18.

Meyer, S.L., D. P. Roberts,D. J. Chitwood, L. K. Carta, R. D.Lumsden, and W. Mao, 2001. Application of Burkholderia cepacia and Trichoderma virens, alone and in combinations, against Meloidogyne 
incognita on bell pepper. Nematropica., 31(1):75-86.

Nordbring Hertz, B., H. B. Jansson, and A. Tunlid, 2006. Nematophagous Fungi. Encyclopedia of Life Sciences. John Wiley and sons, Ltd, Chichester, doi: 10.1038/npg.els.0004293, available online: http://www.els.net/.

Parmar, H.J., N. P.Bodar, H. N. Lakhani, S. V. Patel, V. V. Umrania, and M. M. Hassan, 2015. Production of lytic enzymes by Trichoderma strains during in vitro antagonism with Sclerotiumrolfsii, the causal agent of stem rot of groundnut. Afr. $J$. Microbiol. Res., 9(6):365-372.

Perveen, Kahkashan., and N. A. Bokhari, 2012. Antagonistic activity of Trchidermaharzianumand

Trichoderma virideisolated from soil of date palm field against Fusarium oxysporum. Afr. J. Microbiol. Res., 6(13):3348-3353

Rajinikanth, R., M. S. Rao, K. V.Pavani, R.Manojkumar, M. K. Chaya, K.Rathnamma, andT. N.Shivananda, 2013. Management of nematode induced disease complex in seedlings of cauliflower (Brsassicao leraceae var. botrytis) using bio-pesticides. Pest Manage. Hortic. Ecosyst., 19(2):203210

Rao, M.S. 2007. Papya seedlings colonized by the bio-agents Trichoderma harzianum and Pseudomonas fluorescens to control root-knot nematodes. Nematol. Mediterr., 35(2):199-203.

Rozen. S., and H. Skaletsky, 1999. Primer3 on the WWW for general users and for biologist programmers. In: Krawetz, S., Misener, S. (Eds.). Bioinformatics methods and protocols, Methods in Molecular Biology. Humana Press, Totowa, p.365-386 (New Jersy)

Saeedizadeh, A., 2016.Trichoderma viride and Pseudomonas fluorescens CHA0 against Meloidogynejavanica in the rhizosphere of tomato plants. H. P. P. J., 9(1):28-34

Sahebani, N., and N. Hadavi, 2008. Biological control of the root-knot nematode Meloidogynejavanica by Trichoderma harzianum. Soil Biol. Biochem., 40(8):2016-2020

Savazzini, F., C. M. O. Longa, and I.Pertot, 2009. Impact of the biocontrol agent Trichoderma atroviride SC1 on soil microbial communities of a vineyard in northern Italy. Soil boil. Biochem., 41(7):1457-1465

Seidl, V., B. Huemer,B. Seiboth, and C. P.Kubicek, 2005. A complete survey of Trichodermachitinases reveals three distinct subgroups of family 18 chitinases. FEBS. J., 272(22): 59235939

Shamalie, B.V.T., R. M. Fonseka, and R. G. A. S. Rajapaksha, 2012. Effect of Trichoderma viride and Carbofuran (Curator®) on management of root knot nematodes and growth parameters of Gotukola (Centellaasiatica L.). Trop. Agr. Res., 23(1)

Sharon, E., M. Bar-Eyal, I. Chet, A. Herrera-Estrella, O. Kleifeld, andY. Spiegel, 2001. Biological control of the root-knot nematode Meloidogyne javanica by Trichoderma harzianum. Phytopathol., 91(7): 687-693

Spiegel, Y., E. Sharon, M. Bar-Eyal, A. Maghodia, A. Vanachter, A. Van Assche, S.VanKerckhove, A. Viterbo, andI. Chet, 2007. Evaluation and mode of action of Trichoderma isolates as biocontrol agents against plant-parasitic nematodes. IOBC WPRS BULLETIN 30(6/2) Spa: p. 129(Belgium)

Suarez, B., M. Rey, P. Castillo, E. Monte, andA. Llobell, 2004. Isolation and 
characterization of PRA1, a trypsinlike protease from the biocontrol agent Trichoderma harzianum CECT 2413 displaying nematicidal activity. Appl. Microbiol. Biotechnol., 65(1):46-55

Sudheer Kumar. 2010. Cryopreservation. Short and long term storage of fungal cultures. (Chowdappa P. ed.), ICARIndian Institute of Horticultural Research (IIHR), Bangalore: p. 4-6 (India)

Szabo, M., K. Csepregi, M. Galber, F. Viranyi, andC. Fekete, 2012. Control plant-parasitic nematodes with Trichoderma species and nematodetrapping fungi: The role of Chil8-5 and chil8-12 genes in nematode eggparasitism. Biol. Control., 63(2):121128

Taylor, C.E., 1990. Nematode interactions with other pathogens. Ann. Appl. Biol., 116(3): 405-416.

Verma, M., S. K. Brar, R. D. Tyagi, V. Sahai, D. Prevost, J. R. Valero, and R. Y. Surampalli, 2007. Bench-scale fermentation of Trichoderma virideon waste water sludge: rheology, lytic enzymes and biocontrol activity. Enzyme Microb. Tech., 41(6):764-771

Vinale, F., K. Sivasithamparam, E. L. Ghisalberti, R. Marra, M. J. Barbetti,
H. Li, S. L. Woo, and M.Lorito, 2008. A novel role for Trichoderma secondary metabolites in the interactions with plants. Physiol. Mol. Plant Pathol., 72(1):80-86

Viterbo, A., M. Montero, O. Ramot, D. Friesem, E. Monte, A. Llobell,andI Chet, 2002. Expression regulation of the endochitinasechit36 from Trichoderma asperellum (T. harzianum T-203). Curr. Genet., 42(2): 114-122

Viterbo, A., S. Haran, D. Friesem, O. Ramot, and I. Chet, 2001. Antifungal activity of a novel endochitinase gene (chit36) from Trichoderma harzianum Rifai TM. FEMS. Microbiol. Lett., 200(2): 169-174

Yang, Z.S., G. H. Li, P. J. Zhao, X. Zheng, S. L. Luo, L. Li, X. M. Niu, and K. Q. Zhang, 2010.Nematicidal activity of Trichoderma spp. and isolation of an active compound. World J. Microbiol. Biotechnol., 26(12): 2297-2302

Zeilinger, S., C. Galhaup, K. Payer, S. L. Woo, R. L. Mach, C. Fekete, M. Lorito,andC. P. Kubicek, 1999.Chitinase gene expression during mycoparasitic interaction of Trichoderma harzianum with its host. Fungal Genet. Biol., 26(2): 131-140.

\section{How to cite this article:}

Rajinikanth, R., M.S. Rao, K.V. Pavani and Umamaheswari, R. 2016. Molecular Characterization of Chitinase (chil8-5) and its Expression in Trichoderma viride: Role on Nematode Egg Parasitism. Int.J.Curr.Microbiol.App.Sci. 5(12): 56-64. doi: http://dx.doi.org/10.20546/ijcmas.2016.512.006 